\title{
INSAN KAMIL DALAM PEMIKIRAN MUHAMMAD NAFIS AL-BANJARI DAN ABDUSH-SHAMAD AL-FALIMBÂNî DALAM KITAB AD-DURR AN-NAFIS DAN SIYAR AS-SÂLIKÎN (SEBUAH STUDI PERBANDINGAN) ${ }^{1}$
}

\author{
R o d i a h \\ Jurusan Akidah Filsafat Fakultas Ushuluddin dan Humaniora \\ IAIN Antasari Banjarmasin
}

Diterima tanggal 18 November 2015 / Disetujui tanggal 30 September 2015

\begin{abstract}
This paper tries to explore the concept of Insan Kamil through two books of Sufism, ad-Durr an-Nafis by Muhammad Nafis al-Banjari and Siyar as-Salikin by Abdush-Shamad al-Falimbânî. The method used in this paper comparative descriptive approach, because the studies referred to in this study aims to look at the similarities and differences of the concept of Insan Kamil contained in both books. These results indicate that the thought of Mubammad Nafis al-Banjari in the book ad-Durr an-Nafis and Abdush-Samad al-Falimbân $\hat{\imath}$ in the book Siyar al-Salikin against the concept of Insan Kamil has the same basic concept, in addition to the typical thinking its own distinct between the two.
\end{abstract}

Kata kunci: Insan Kamil, ad-Durr an-Nafis, Siyar as-Sâlikîn, Perbedaan, Persamaan.

\section{Pendahuluan}

Transmisi tradisi intelektual-keagamaan dari basis intelektual Islam yang berpusat di Haramayn pada abad XVII dan XVIII M memunculkan gejolak dan dinamika pemikiran Islam Nusantara. Hal tersebut salah satunya ditandai dengan banyaknya literatur ilmiah keagamaan yang dihasilkan. Sejumlah ulama terkemuka yang berkontribusi dalam pembentukan tradisi intelektual Islam menghubungkan berbagai doktrin, konsep, ajaran, dan pemikiran intelektual keagamaan yang berkembang di Haramayn ke Nusantara. ${ }^{2}$ Kecenderungan para ulama Nusantara pada masa tersebut adalah mistis-filosofis yang dipadukan dengan sufisme. Wacana ilmiah yang muncul pada periode tersebut salah satunya adalah konsep Insan Kamil.

Konsep Insan Kamil yang muncul dalam dunia tasawuf sekitar abad VII H/XIII M pada akhirnya berkembang dalam pemikiran Islam hingga ke Nusantara. Dalam wacana Islam Nusantara, konsep Insan Kamil dibahas secara khusus dalam kitab-kitab tasawuf. Tingkat pemahaman yang berbeda membuat paradigma yang ditemukan menghasilkan asumsi beragam antara berbagai kitab. Berangkat dari kenyataan tersebut, perlu adanya kajian yang bertujuan untuk menjelaskan dan memberikan pemahaman yang baik terhadap konsep Insan Kamil dari kitab tasawuf. Kajian terhadap konsep Insan Kamil dipilih pada dua kitab tasawuf sekaligus, yaitu kitab ad-Durr an-Nafis karya Muhammad Nafis al-Banjari dan Siyar as-Sâlikîn karya AbdushShamad al-Falimbânî.

\footnotetext{
${ }^{1}$ Tulisan merupakan skripsi pada jurusan Akidah Filsafat Fakultas Ushuluddin dan Humaniora

${ }^{2}$ Oman Fathurahman, Ithaf al-Dhaki Tafsir Wabdatul Wujud Bagi Muslim Nusantara (Bandung: Mizan, 2012), 50.
} 


\section{Hakikat Insan Kamil}

Insan Kamil berasal dari bahasa Arab, insan dan kamil. ${ }^{3}$ Insan berarti manusia, sedangkan kamil artinya sempurna. ${ }^{4}$ Dari segi pemaknaan istilah Insan Kamil memiliki berbagai definisi beragam yang diantaranya diartikan sebagai manusia yang telah sampai pada tingkat tertinggi (fana' fillab). ${ }^{5}$ Makna lain Insan Kamil adalah manusia paripurna sebagai wakil Allah untuk mengaktualisasikan diri, merenungkan dan memikirkan kesempurnaan yang berasal dari namaNya sendiri. ${ }^{6}$

Ibn'Arabi menjelaskan bahwa Insan Kamil memiliki dua kesempurnaan yaitu kesempurnaan dzati (esensial) dan kesempurnaan aradl (aksidental). Kesempurnaan dzati berhubungan dengan realitas esensi sebagai "bentuk" Tuhan sehingga manusia sempurna sama dan "menyatu" dengan Tuhan sebagai satu realitas. Kesempurnaan aradl berhubungan dengan pengejawantahan sifatsifat serta kualitas yang ternyatakan dalam peran khusus yang menimbulkan keunikan tersendiri. ${ }^{7}$ Insan Kamil menurut al-jili mempunyai dua pengertian. Pertama, konsep pengetahuan manusia yang sempurna terkait dengan sesuatu yang dianggap mutlak yaitu Tuhan. Kedua, jati diri yang mengidealkan kesatuan nama serta sifat Tuhan kedalam hakikat diri atau esensinya. ${ }^{8}$

\section{Akar Historis Konsep Insan Kamil Dalam Tasawuf}

Istilah Insan Kamil secara teknis muncul sekitar abad VII H/XIII M atas gagasan Ibn 'Arabi yang dikembangkan oleh Abdul Karim al-Jili.' Sebelum Ibn 'Arabi terdapat konsep pemikiran yang mirip dengan substansi konsep Insan Kamil. Konsep yang muncul terdahulu tersebut, tidak hanya datang dari Islam tetapi juga dari luar Islam. Meskipun demikian, asal konsep Insan Kamil lebih dipercaya berasal dari Islam secara murni.

Di antara konsep terdahulu dalam Islam yang mirip dengan konsep Insan Kamil adalah doktrin hermetic seperti yang diungkapkan Jabir ibn Hayyan dalam naskah Arab mengenai "lempengan mutiara" yakni sesuatu yang di bawah tidak ubahnya yang di atas. Makna pengertian tersebut bahwa alam kecil (manusia ketika menyadari asal usul kejadiannya yang diciptakan dalam rupa Tuhan) diciptakan sesuai dengan prototipe alam besar. ${ }^{10}$ Teori Insan Kamil juga terkait pembicaraan sufi pada pertengahan abad III H bahwa dirinya telah menyatu dengan Tuhan dengan sejumlah nama-Nya sehingga mencapai fana (mengacu pada teori yang dikemukakan Abu Yazid Busthami). Selanjutnya dikemukakan oleh al-Hallaj yang percaya bahwa

${ }^{3}$ Abuddin Nata, Akblak Tasawuf(Jakarta: Raja Grafindo Persada, 2009), 257.

${ }^{4}$ Mahmud Yunus, Kamus Arab Indonesia (Jakarta: Hidakarya Agung, 1990), 51 dan 383.

${ }^{5}$ Asmaran AS, Pengantar Studi Tasawuf (Jakarta: Raja Grafindo Persada, 1994), 345.

${ }^{6}$ Amatullah Armstrong, Kunci Memasuki Dunia Sufi, terj. M. S. Nashrullah dan Ahmad Baiquni (Bandung: Mizan, 2001), 118.

${ }^{7}$ William C. Chittick, The Sufi Path of Knowledge Pengetahuan Spiritual, terj. Achmad Nidjam, M. Sadat Ismail, dan Ruslani (Yogyakarta: Penerbit Qalam, 2001), 342-343.

${ }^{8}$ Dewan Redaksi Ensiklopedi Islam, Ensiklopedi Islam (Jakarta: Ichtiar Baru van Hoeve, 2001), 227. Asmaran As, Pengantar Studi.., 349. M. Fatih Suryadilaga, Miftahus Sufi (Yogyakarta: Teras, 2008), 218.

${ }^{9}$ Yunasril Ali, Manusia Citra Ilabi Pengembangan Konsep Insan Kamil Ibn 'A rabi oleh al-Jili (Jakarta: Paramadina, 1997), 6 dan Murtadha Muthahhari, Manusia Sempurna, terj. Helmi Mustofa (Yogyakarta: Al-Ghiyatd Prisma Media, 2004$), 4$.

${ }^{10}$ Cyril Glasse, Ensiklopedi Islam (Ringkas), terj, Ghufron A. Mas'adi (Jakarta: Raja Grafindo Persada, 2002), 170. Totok Jumantoro dan Samsul Munir Amin, Kamus Ilmu Tasamuf (t.t.: AMZAH, 2005), 93. 
Tuhan menciptakan Adam menyerupai wajah-Nya sebagai representasi Tuhan, cermin keindahan wajah-Nya, serta manifestasi-Nya yang abadi (dikenal dengan teori bulul). ${ }^{11}$

Konsep dari luar Islam yang mirip dengan konsep Insan Kamil adalah konsep manusia sempurna yang terdapat dalam tradisi Yahudi tentang Qabbalab sebagai adam kadmon (asal usul manusia pertama) dan berkaitan erat dengan teori yang berkembang di abad pertengahan tentang "rangkaian besar suatu wujud" yang menunjukkan bahwa terdapat hierarki yang mencakup segala jenis penciptaan dan manusia merupakan sintetis dari seluruh penciptaan. ${ }^{22}$ Konsep Insan Kamil juga dipandang berasal dari agama Parsi kuno tentang Gayomard sebagai manusia pertama yang memiliki daya ilahi serta berperan penting dalam penciptaan. ${ }^{13}$ Selain itu, terdapat pula ide tentang anthropos teleios yang dipahami sebagai manusia sempurna dalam falsafah Yunani. ${ }^{14}$

Secara historis konsep yang merujuk kepada pengertian Insan Kamil dalam Islam dimulai pada awal abad III H yang diperkenalkan oleh Abu Yazid Bustami tentang al-wali al-kamil (wali yang sempurna) yaitu orang yang telah mencapai ma'rifat yang sempurna tentang Tuhan sehingga fana dalam nama-Nya. ${ }^{15}$ Konsep ini kemudian dimatangkan oleh al-Hallaj dengan doktrin bahwa manusia (Adam) dipandang sebagai penampakan lahir dari cinta Tuhan. Selanjutnya Insan Kamil dikemukakan oleh al-Hakim al-Tirmidzi dengan label khatm al-awliya yakni seseorang yang berada pada peringkat tertinggi di hadapan Allah. ${ }^{16}$

Tokoh selanjutnya yang dianggap membahas Insan Kamil adalah Ibn' Sab'in. Ibn Sab’in menamakan Insan Kamil dengan al-mubaqiq yang merupakan penampakan lahir dari Wujud Mutlak secara paripurna. Konsep Insan Kamil mencapai kematangan di tangan Ibn 'Arabi dalam dua karya utamanya, Fusus al-Hikam dan Futuhat Makkiyah. Pemikiran Ibn 'Arabi kemudian dikembangkan oleh Abdul Karim al-Jili dalam bukunya, al-Insan al-Kamil fi Ma'rifat wa al-Awakbir wa al-Awail. Dalam perkembangan selanjutnya, muncul seorang tokoh yang dikenal dengan al-Burhanfuri memperkenalkan teori martabat tujub yang turut memengaruhi konsep Insan Kamil.

Kajian Insan Kamil di Nusantara tidak dapat dipisahkan dari masuk dan berkembangnya Islam di Nusantara. ${ }^{17}$ Antara abad XII M dan XV M, Muslim Arab dan Persia mulai mengintensifkan penyebaran Islam di wilayah Nusantara. Pada pertengahan kedua abad XVII M, umat Islam Nusantara mulai menjalin hubungan politik dan keagamaan dengan Haramayn sehingga banyak yang datang ke sana dan pada akhirnya menciptakan jalinan keilmuan antara ulama Timur Tengah dan muslim Nusantara. ${ }^{18}$

Sketsa Biografi Intelektual Muhammad Nafis al-Banjari dan Tentang Kitab ad-Durr anNafis

${ }^{11}$ Seyyed Mohsen Miri, Sang Manusia Sempurna Antara Filsafat Islam dan Hindu, terj. Zubair (Jakarta: Teraju, 2004), 22.

${ }^{12}$ Glasse, Ensiklopedi Islam..., 170.

${ }^{13}$ Dikutip dalam Ali, Manusia Citra..., 6.

${ }^{14}$ Seyyed Hossein Nasr, The Garden of Truth Mereguk Sari Tasawuf, terj. Yuliani Liputo (Bandung: Mizan, 2010$), 37$.

${ }^{15}$ Ali, Manusia Citra..., 8.

${ }^{16}$ Asep Usman Ismail, Apakah Wali Itu Ada? Menguak Makna Kewalian Dalam Tasawuf Pandangan al-hakim al-Tirmidji dan Ibn Taymiyyah (Jakarta: Raja Grafindo Persada, 2005), 141.

${ }^{17}$ Ali, Manusia Citra..., 182.

${ }^{18}$ Nor Huda, Islam Nusantara Sejarah Sosial Intelektual Islam di Indonesia (Yogyakarta: Ar-Ruzz Media, 2007$)$, 181. 
Muhammad Nafis diperkirakan lahir pada tahun 1148 H/1735 M di Martapura, Kabupaten Banjar, Provinsi Kalimantan Selatan dari keluarga bangsawan Banjar. ${ }^{19}$ Tahun kewafatannya tidak diketahui secara pasti, tetapi ada yang memperkirakan tahun 1812 M. ${ }^{20}$ Terdapat tiga tempat yang diduga sebagai makam Nafis yakni di desa Kelua, Kusan, dan Sigam. ${ }^{21}$ Di antara ketiga tempat tersebut, Kelua menjadi lokasi yang paling banyak dikunjungi. ${ }^{22}$

Pendidikan awal Nafis tidak begitu jelas, tetapi kemungkinan besar bermula dari menuntut ilmu agama di Kalimantan. ${ }^{23}$ Kecenderungan Nafis terhadap tasawuf mulai terlihat sejak kecil. ${ }^{24}$ Nafis meneruskan pendidikan ke Haramayn (Mekkah dan Madinah). Beberapa nama yang diyakini sebagai guru-guru Nafis antara lain Abdullah Hijazi as-Syarkawi al-Azhari $(1150 \mathrm{H} /$ 1737 M-1227 H/1812 M), Muhammad bin Abdul Karim as-Samman al-Madani (1132 H-2 Dzulhijjah 1189 H), Abdurrahman bin Abdul Aziz al-Maghribi, Shiddiq bin Umar Khan, Muhammad al-Jawhari al-Mishri (1132 H/1720 M-1186 H/1172 M), Yusuf Abu Dzarrah alMishri, Abdullah bin Ibrahim al-Mirghani (wafat 1207 H/1792 M), dan Abu Fauzi Ibrahim bin Muhammad al-Ra'is al-Zamzami al-Makki (1110 H-1194 H). ${ }^{25}$

Muhammad Nafis mengikuti mazhab Syafi'i dalam bidang fikih, doktrin Asy'ari dalam kalam, dan pengikut Junaid dalam bidang tasawuf serta berafiliasi dengan beberapa tarekat (seperti tarekat Qadiriyah, Syaththariyah, Sammaniyah, Naqsyabandiyah, dan Khalwatiyah). ${ }^{26}$ Semua tarekat yang dianut oleh Nafis tergolong tarekat yang masyhur.

Nama kitab ad-Durr an-Nafis selengkapnya adalah ad-Durr an-Nafis fi Bayân Wahdah al-Af'âl wa al-Asmâ' wa ash-Shifât Zât at-Taqdis (Mutiara yang Indah Pada Menyatakan Wabdat Af'al dan Asma dan Shifat dan Zat Yang Suci). ${ }^{27}$ Kitab ad-Durr an-Nafis yang selesai ditulis setelah waktu isya pada malam Rabu 27 Muharam tahun $1200 \mathrm{H}$ atau 30 November 1785 M, ,8 merupakan kitab kecil dan tipis berbahasa Arab Melayu yang isinya sangat padat mengenai ajaran tauhid tasawuf tingkat tinggi menjelaskan tentang keesaan Allah dari zât, shifât, asmâ', dan af'âl. ${ }^{29}$

${ }^{19}$ Azyumardi Azra, Jaringan Ulama Timur Tengah dan Kepulauan Nusantara Abad XVII dan XV III Melacak. Akar-Akar Pembaruan Pemikiran Islam di Indonesia (Bandung: Mizan, 1998), 255. Heri Faridy, Rahmat Hidayat, dan Ika Prasasti Wijayanti, ed., Ensiklopedi Tasawnf Jilid II (Bandung: Angkasa, 2008), 851. Sri Mulyati, Tasawnf Nusantara Rangkaian Mutiara Sufi Terkemuka (Jakarta: Kencana, 2006), 113. Tim Sahabat, Syekh Mubammad Nafis al-Banjari dan Ajarannya (Kandangan: Sahabat, 2010), 3. Tim Sahabat, 27 Ulama Berpengarub Kalimantan Selatan (Kandangan: Sahabat, 2010), 10.

${ }^{20}$ Tim Sahabat, Syekh Muhammad..., 3. Terdapat kesan bahwa Nafis tidak meninggal di Kalimantan melainkan di Mekkah. Asywadie Syukur, Filsafat Tasawuf dan Aliran-alirannya (Banjarmasin: Antasari Press, 2009), 120.

${ }^{21}$ Martin Van Bruinessen, Kitab Kuning Pesantren dan Tarekat Tradisi-Tradisi Islam di Indonesia (Bandung: Mizan, 1999), 65.

${ }^{22}$ Van Bruinessen, Kitab Kuning..., 65.

${ }^{23}$ Tim Sahabat, Syekh Muhammad..., 6. Azra, Jaringan Ulama..., 255.

${ }^{24}$ Ahmadi Isa, Ajaran Tasawuf Mubammad Nafis Dalam Perbandingan (Jakarta: Raja Grafindo Persada, 2001), 26.

${ }^{25}$ Tim Sahabat, Syekh Muhammad..., 7-12. Tim Sahabat, 27 Ulama..., 12-16. Tim Penulis IAIN, Ensiklopedi Islam (Jakarta: Djambatan, 1992), 677.

${ }^{26}$ Muhammad Nafis ibn Idris al-Banjari, Ad-Durr an-Nafis fi Bayan Wabdat al-Af'al wa al-Asma' wa ash-Shifat Zat atTaqdis (Singapura, Jedah, Indonesia: Haramayn, t.th), 38. Bayani Dahlan, ed., Ulama Banjar dan Karya-karyanya (Banjarmasin: Antasari Press, 2009), 193. Azra, Jaringan Ulama..., 257.

${ }^{27}$ Nafis al-Banjari, Ad-Durr an-Nafis..., 3. Tim Sahabat, Syekh Muhammad..., 50. Muhammad Nafis bin Idris alBanjari, Ad-durrunnafis, alih bahasa Haderanie HN dengan judul Ilmu Ketuhanan Permata yang Indah Ad-durrunnafis (Surabaya: Nur Ilmu, t.th), 17. Mawlana al-'Allamah al-Fahamah, Hakikat Jalan Sufi Keesaan Af'al Asma' Shifat dan Dzatyang Suci, terj. Agus Wahyudi (Yogyakarta: Qalam, 2003), vii.

${ }^{28}$ Tim Sahabat, Syekh Muhammad..., 14. Tim Sahabat, 27 Ulama..., 16-17. Tahun ini diperoleh dari ungkapan Nafis sendiri dalam kitab ini dengan kalimat "Pada tahun seribu dua ratus daripada hijrah Nabi yang mulia", artinya 1200 tahun setelah Nabi hijrah atau 1200 H. Nafis al-Banjari, Ad-Durr an-Nafis ..., 2. 
Dalam bidang tasawnf, kitab ini termasuk dalam kategori kitab orangyang sudah muntabi, yaitu tingkatan terakhir dalam keilmuan tasanuf bagi orang yang sudah mencapai tingkat arif billah (orang yang mencapai hakikat) yang keilmuannya telah matang dan hatinya tidake pernab lupa kepada Allah. ${ }^{30}$

Sketsa Biografi Intelektual Abdush-Shamad al-Falimbânî dan Tentang Kitab Siyar as-Sâlikîn

Abdush-Shamad al-Falimbânî diperkirakan lahir sekitar 1116 H/1704 M. ${ }^{31}$ Tahun meninggal Shamad diperkirakan tahun 1203 H/1789 M setelah menyelesaikan karya terakhir, Siyar as-Salikîn. ${ }^{32}$ Ada yang mengatakan bahwa Shamad meninggal akibat terbunuh dalam perang melawan Thai (perang antara kesultanan Kedah dan Siam). ${ }^{33}$ Daerah yang diduga tempat meninggal Shamad antara lain di perbatasan Malaysia (Kedah) dan Siam, di Patani Thailand Selatan, dan di Arabia. ${ }^{34}$

Shamad hidup di lingkungan spiritual yang masyarakatnya sangat antusias terhadap tasawuf..$^{35}$ Pendidikan awal Shamad dimulai dengan mempelajari al-Qur'an dan ilmu agama di Palembang. Pendidikan tersebut membuat Shamad menjadi hafidz di usia muda yaitu ketika berusia sembilan tahun. ${ }^{36}$ Masa kecil Shamad selanjutnya dihabiskan di Kedah di bawah bimbingan ayahnya sendiri. ${ }^{37}$ Pendidikan keagamaan mereka kemudian dilanjutkan ke pondok pengajian di negeri Patani yang kemungkinan bernama Pondok Bendang Gucil Keresik, Pondok Kuala Bekah, dan Pondok Semala. ${ }^{38}$ Sistem yang diterapkan pada masa itu adalah hapalan dari dasar ilmu bahasa Arab seperti nabwu dan sharaf, lalu dilanjutkan dengan ilmu Alat Dua Belas, kemudian dasar ilmu syariat dalam mazhab fikih serta dasar tauhid berdasarkan Ablus Sunnah wal Jamaah. Disayangkan sekali tidak ditemukan nama guru Shamad sewaktu di Pattani. ${ }^{39}$ Shamad juga sempat mempelajari tasawuf dari kitab sufi ulama Aceh Syamsuddin al-Sumatrani dan Abdur Rauf al-Fansuri (Abdur Rauf Singkel). ${ }^{40}$ Pendidikan Shamad selanjutnya diteruskan di Mekkah dan Madinah. Kurang lebih 30 tahun masa studi Shamad di Mekkah. ${ }^{41}$

\footnotetext{
${ }^{29}$ Tim Sahabat, 27 Ulama..., 18. Nafis al-Banjari, Ad-Durr an-Nafis..., h. 2. Penulisan kitab dengan menggunakan bahasa Melayu kemungkinan bertujuan agar dapat dimanfaatkan oleh yang belum mengerti bahasa Arab dengan baik. Isa, Ajaran Tasawnf..., 26.

${ }^{30}$ Syukur, Filsafat Tasawnf..., 27.

${ }^{31}$ Muhsin Labib, Mengurai Tasawnf Irfan \& Kebatinan (Jakarta: Lentera, 2004), 231. Harun Nasution, dkk, ed., Ensiklopedi Islam I (Jakarta: Anda Utama, 1993), 32. M. Solihin, Sejarah dan Pemikiran Tasanuf di Indonesia (Bandung: Pustaka Setia, 2001), 62. Tim Penulis IAIN, Ensiklopedi Islam..., 33. Mulyati, Tasawnf Nusantara..., 106.

${ }^{32}$ Waini Hambali al-Banjari, Manakib Syekh Abdush Shamad al-Falimbani (Kandangan: Sahabat, 2012), 4. Abdus Shamad al-Falimbani, Sairus Salikin (Perjalanan Orang yang Salik Kepada Allab), pentahqiq Ahmad Fahmi bin Zamzam (Banjarbaru: Darussalam Yasin, 2010), xviii. Abdus Shamad al-Falimbani, Hidayatus Salikin fi Suluki Maslakil Muttaqin (Petunjuk Jalan Bagi Orang yang Takut Kepada Allah Taala), pentahqiq Ahmad Fahmi bin Zamzam (Banjarbaru: Darussalam Yasin, 2008), xxv.

${ }^{33}$ Akbarizan, Tasawuf Integratif Pemikiran dan Ajaran Tasawnf di Indonesia (Pekanbaru: Suska Press, 2008), 89. Hambali alBanjari, Manakib Syekh..., h. Shamad al-Falimbani, Sairus Salikin..., xviii. Shamad al-Falimbani, Hidayatus Salikin..., xxv.

${ }^{34}$ Azra, Jaringan Ulama ..., 245-246.

${ }^{35}$ Alwi Shihab, Islam Sufistik Islam Pertama dan Pengarubnya Hingga Kini di Indonesia (Bandung: Mizan, 2001), 70.

${ }^{36} \mathrm{Mal}$ An Abdullah, Abdus Samad al-Palimbani Data Baru Tentang Hayat dan Karyanya, h. 1733, t.t. (22 Desember 2014), 1733. Terdapat nama yang dipercayai sebagai guru Shamad sewaktu masih di Palembang, yaitu Sayyid Hasan bin Umar Idrus. Abdullah, Abdus Samad..., 1737.

${ }^{37}$ Hambali al-Banjari, Manakib Syekh..., 11.

${ }^{38}$ Hambali al-Banjari, Manakib Syekh..., 11.

${ }^{39}$ Hambali al-Banjari, Manakib Syekh..., 11-12.

${ }^{40}$ Mulyati, Tasawuf Nusantara..., 106.

${ }^{41}$ Hambali al-Banjari, Manakib Syekh..., 12-13.
} 
Secara umum yang termasuk nama guru Shamad antara lain Muhammad bin Abdul Karim al-Sammani, Muhammad bin Sulayman al-Kurdi, Abdul al-Mun'im al-Damanhuri, 'Abu alFawz 'Ibrahim bin Muhammad az-Zamzami ar-Ra'is al-Makki, Muhammad Murad, Muhammad al-Jawhari al-Mashri, dan Athaillah bin Ahmad al-Azhari al-Mashri al-Makki. ${ }^{42}$ Jika melihat deretan nama guru Shamad nampak bahwa pendidikan Shamad sangat tuntas dalam berbagai rumpun ilmu terutama tasawuf. ${ }^{43}$

Judul lengkap kitab Siyar as-Sâlikin adalah Siyar as-Sâlikîn fi Thariqah as-Sâdât ash-Shûfîyah. Dalam penerbitan lain lebih banyak menyebutkan judul lengkap kitab ini dengan Sair as-Sâlikîn ila Ibadah Rabb al-Alamin. Siyar as-Sâlikîn merupakan kitab tasawuf dalam bahasa Arab Melayu yang terdiri atas empat bagian. Bagian pertama membahas tentang ilmu ushuluddin dan segala masalah yang berkaitan dengan ibadah zabir (ditulis pada 1193 H/1779 M dan selesai pada awal tahun $1194 \mathrm{H} / 1780 \mathrm{M}$ di Mekah). ${ }^{44}$ Bagian kedua membahas hukum dan adab yang berlaku dalam kehidupan (mulai ditulis pada 1194 H/1780 M dan selesai pada hari Sabtu, 19 Ramadan $1195 \mathrm{H} / 1781 \mathrm{M}$ di Thaif). ${ }^{45}$ Bagian ketiga membahas maksiat yang membinasakan amal (mulai ditulis pada tahun $1195 \mathrm{H} / 1781 \mathrm{M}$ dan diselesaikan pada 19 Safar $1197 \mathrm{H} / 1783 \mathrm{M}$ di Mekkah). ${ }^{46}$ Bagian keempat membahas ibadah batin (tidak disebutkan tahun penulisannya, sedangkan selesainya pada 20 Ramadan 1203 H/1788 M di Thaif). ${ }^{47}$ Sebagian besar isi kitab ini adalah merupakan terjemahan dari Lubab Ibya (mukhtasar atau ringkasan kitab Ibya Ulumiddin karya alGhazali). Shamad sendiri menggolongkan kitab ini sebagai kitab tasawuf mubtadi (pemula). ${ }^{48}$

Perbandingan Konsep Insan Kamil Dalam Kitab ad-Durr an-Nafis dan Siyar as-Salikîn

1. Pengertian Insan Kamil

Insan Kamil menurut Nafis adalah orang yang telah mencapai ma'rifat dalam hal tauhid (af'al, asma, shifat, dan zat) serta sebagai hasil akhir dalam martabat tanazul. ${ }^{49}$ Pengertian Insan Kamil menurut Shamad adalah orang yang telah memperoleh ma'rifat kepada Allah Swt. dan sebagai perwujudan terakhir tajalli Tuhan. ${ }^{50}$ Pernyataan tersebut mengarah kepada isyarat bahwa kedua tokoh tersebut sama-sama memandang Insan Kamil dalam dua pengertian, yaitu sebagai orang yang telah benar-benar mengenal Tuhan (ma'rifat) dan sebagai perwujudan tajalli Tuhan. Pengertian Insan Kamil sebagai orang yang telah mencapai ma'rifat

${ }^{42}$ Azra, Jaringan Ulama..., 247.

${ }^{43}$ Azra, Jaringan Ulama..., 249.

${ }^{44}$ Abdus Shamad al-Falimbânî, Siyar as-Sâlikîn fi Thariqah as-Sâdât ash-Shûfîyah Juz I (Singapura, Jedah, Indonesia: Haramayn, t.th), 241. Abdus Shamad al-Falimbani, Sairus Salikin (Perjalanan Orang yang Salik Kepada Allah) Juz Pertama, pentahqiq Ahmad Fahmi bin Zamzam (Banjarbaru: Darussalam Yasin, 2010), 604.

${ }^{45}$ Abdus Shamad al-Falimbânî, Siyar as-Sâlikîn fi Thariqah as-Sâdât ash-Shûfîyah Juz. II (Singapura, Jedah, Indonesia: Haramayn, t.th), 248. Abdus Shamad al-Falimbani, Sairus Salikin (Perjalanan Orang yang Salik Kepada Allah) Juz. Kedua, pentahqiq Ahmad Fahmi bin Zamzam (Banjarbaru: Darussalam Yasin, 2010), 599.

${ }^{46}$ Abdus Shamad al-Falimbânî, Siyar as-Sâlikîn fi Thariqah as-Sâdât ash-Shûfîyah Juz III (Singapura, Jedah, Indonesia: Haramayn, t.th), 208. Abdus Shamad al-Falimbani, Sairus Salikin (Perjalanan Orang yang Salik Kepada Allah) Juz Ketiga, pentahqiq Ahmad Fahmi bin Zamzam (Banjarbaru: Darussalam Yasin, 2010), 499.

${ }^{47}$ Abdus Shamad al-Falimbânî, Siyar as-Sâlikîn fi Thariqah as-Sâdât ash-Shûfîyah Juz IV (Singapura, Jedah, Indonesia: Haramayn, t.th), 267. Abdus Shamad al-Falimbani, Sairus Salikin (Perjalanan Orangyang Salik Kepada Allab) Juz. Keempat, pentahqiq Ahmad Fahmi bin Zamzam (Banjarbaru: Darussalam Yasin, 2010), 660.

${ }^{48}$ Shamad al-Falimbânî, Siyar as-Sâlikîn...Juz III, 177. Shamad al-Falimbani, Sairus Salikin...Juž Ketiga, 428.

${ }^{49} \mathrm{Nafis}$ al-Banjari, Ad-Durr an-Nafis..., 2 dan 23. 
merujuk pada upaya untuk mencapai Insan Kamil, sedangkan Insan Kamil dalam pengertian wadah tajalli Tuhan merujuk pada gambaran kemunculan Insan Kamil.

2. Tingkatan Insan Kamil

Dalam konsep Insan Kamil Nafis dan Shamad terlihat bahwa keduanya memiliki pandangan yang sama bahwa Insan Kamil memiliki tingkatan. Nafis hanya menyiratkan adanya tingkatan tersebut dari uraian dalam penjelasan martabat versi Nafis. ${ }^{51}$ Sedangkan tingkatan Insan Kamil Shamad dijelaskan melalui tingkatan empat maqamat tauhid (tingkat munafik, awam, khawwash atau muqarrabin, dan khawwashul khawwash)..$^{52}$

3. Derajat Tertinggi Insan Kamil

Nafis dan Shamad sependapat bahwa tingkat tertinggi Insan Kamil adalah Nabi Muhammad $\mathrm{SAW}^{53}$ Nafis dalam kitabnya tidak memberikan penjelasan panjang mengenai Nabi Muhammad SAW sebagai tingkat tertinggi Insan Kamil. Sedangkan Shamad memberikan penjelasan tuntas mengenai Nabi Muhammad SAW sebagai tingkat tertinggi Insan Kamil. Menurut Shamad ma'rifat Nabi Muhammad SAW merupakan ma'rifat paling sempurna bahkan diantara nabi dan wali, sehingga menjadikan Nabi Muhammad SAW sebagai bentuk paling sempurna Insan Kamil. Shamad bahkan memberikan penjelasan pada satu bab khusus perihal Nabi Muhammad SAW dalam kitab Siyar as-Sâlikîn. Shamad menegaskan bahwa Allah memang melebihkan Nabi Muhammad SAW di atas nabi lain sehingga menjadikan Nabi Muhammad SAW sebagai penghulu manusia. ${ }^{54}$

4. Insan Kamil Sebagai Pemberian Allah SWT dan Insan Kamil Harus Tetap Berpegang Syariat

Nafis berpendapat bahwa Insan Kamil merupakan pemberian Allah kepada hamba yang diterima secara langsung. ${ }^{55}$ Dalam konsep Insan Kamil Shamad juga ditemukan asumsi bahwa Insan Kamil merupakan pemberian Tuhan. ${ }^{56}$ Potensi untuk memperoleh Insan Kamil dimiliki oleh hamba Allah tanpa kecuali, namun pemberian derajat Insan Kamil tersebut diperoleh setelah hamba melalui perjalanan sehingga mencapai ma'rifat. Pendapat bahwa Insan Kamil adalah pemberian Allah merupakan pendapat mayoritas tokoh yang membahas Insan Kamil. Selain itu, Nafis dan Shamad juga sependapat bahwa Insan Kamil harus tetap berpegang dengan syariat. ${ }^{57}$

5. Pencapaian Insan Kamil Melalui Maqamat

a. Maqamat Berakhir Pada Fana dan Baqa

Nafis dan Shamad sepakat bahwa Insan Kamil dapat dicapai melalui perjalanan maqamat. Nafis menegaskan bahwa Insan Kamil diperoleh setelah hamba mencapai fana dan baqa..$^{58}$ Dalam pandangan Nafis mengesakan Allah pada zat yang merupakan

\footnotetext{
${ }^{50}$ Shamad al-Falimbânî, Siyar as-Sâlikîn...Juz.IV , 104-106.

${ }^{51} \mathrm{Nafis}$ al-Banjari, Ad-Durr an-Nafis..., 4-14.

${ }^{52}$ Shamad al-Falimbânî, Siyar as-Sâlikîn ... Juz III, 102-103.

${ }^{53}$ Nafis al-Banjari, Ad-Durr an-Nafis..., 11. Shamad al-Falimbânî, Siyar as-Sâlikîn...JužIV, 106.

${ }^{54}$ Shamad al-Falimbânî, Siyar as-Sâlikîn ...Juz I, 31.

${ }^{55}$ Nafis al-Banjari, Ad-Durr an-Nafis..., 2.

${ }^{56}$ Shamad al-Falimbânî, Siyar as-Sâlikîn ...Juz IV, 106.

${ }^{57}$ Nafis al-Banjari, Ad-Durr an-Nafis..., 5. Shamad al-Falimbânî, Siyar as-Sâlikîn ...Juz III, 12.

${ }^{58}$ Nafis al-Banjari, Ad-Durr an-Nafis..., 14 dan 17.
} 
kedudukan tertinggi sebagai titik puncak pengetahuan makhluk tentang Allah atau tujuan terakhir perjalanan menuju Allah dilakukan dengan memandang melalui pandangan batin bahwa tidak ada maujud selain Allah yang berarti perbuatan makhluk fana pada perbuatan Allah, nama hamba fana pada nama Allah, sifat makhluk fana pada sifat Allah, dan zat hamba fana pada wujud zat Allah. Setelah itu, maka pandangan lebur (baqa) bahwa kenyataan alam yang beraneka ragam karena adanya Allah. ${ }^{59}$

Maqamat versi Shamad berakhir pada martabat nafsu kamalah dengan pandangan syubudul katsrah fi wabdah dan syubudul wabdah fi katsrah. ${ }^{60}$ Meskipun maqamat Shamad diungkapkan melalui metode tujuh tingkatan nafsu, tujuan akhir maqamat tetap sama yaitu fana dan baqa. Menurut Shamad pada martabat terakhir pandangannya adalah syubudul katsrab fi wahdah dan syubudul wahdah fi katsrah yakni memandang akan segala makhluk dalam ketuhanan yang Esa, maksudnya sifat ketuhanan terdapat di alam dan sekalian makhluk.

b. Jumlah dan Sistematika Maqamat

Nafis membatasi maqamat hanya pada empat tingkatan tauhid dan memperhatikan sistematikanya yaitu dimulai dengan tauhid af'al, kemudian tauhid asma', lalu tauhid af'al, dan puncaknya pada tauhid zat. ${ }^{61}$

Berbeda dengan pencapaian Insan Kamil melalui maqamat menurut Shamad yang dilakukan dengan menguasai atau menundukkan tujuh tingkatan nafsu yaitu nafsu ammarah, lawwamah, mulhamah, muthmainnah, radiah, mardhiah, dan kamalah. ${ }^{62}$ Setiap nafsu pada setiap tingkat memiliki karakter dan sifat tersendiri, sehingga untuk menundukkan diperlukan usaha yang tidak terlepas dari syariat, tarekat, dan ma'rifat sampai memperoleh bakikat.

Maqamat nafsu Shamad dapat pula dikaitkan dengan tajalli, sebab dalam penjelasannya Shamad juga disebutkan alam-alam seperti dalam konsep tajalli pada umumnya. Dalam konsep Shamad nafsu ammarah alamnya adalah alam syahadat yakni alam ajsam, nafsu lawwamah alamnya adalah alam barzakh yaitu alam mitsal, nafsu mulhamah alamnya adalah alam arwah, nafsu muthmainnah alamnya adalah haqiqat Mubammadiyah dan merupakan martabat ta'yinul awal atau wabdah, nafsu radhiah alamnya adalah alam labut yaitu alam zat dan merupakan martabat ahadiyah, nafsu mardhiah alamnya adalah alam ajsad, dan nafsu kamalah alamnya adalah menghimpun alam sebelumnya. ${ }^{63}$ Dalam konsep maqamat Nafis tidak ditemukan pendapat seperti Shamad di atas, Nafis memberikan penjelasan terhadap tajalli dalam persoalan kemunculan Insan Kamil saja.

Selain melalui penguasaan tingkatan nafsu, Shamad juga mengungkapkan bahwa pencapaian Insan Kamil dilakukan dengan menempuh perjalanan maqamat. Maqamat Shamad terdiri dari 10 maqamat yaitu taubat, sabar dan syukur, raja' dan khauf, fakir

\footnotetext{
${ }^{59}$ Nafis al-Banjari, Ad-Durr an-Nafis..., 15-17.

${ }^{60}$ Shamad al-Falimbânî, Siyar as-Sâlikîn...Juz III, 12.

${ }^{61} \mathrm{Nafis}$ al-Banjari, Ad-Durran-Nafis..., 21-23.

${ }^{62}$ Shamad al-Falimbânî, Siyar as-Sâlikîn...Juz III, 8-12.

${ }^{63}$ Shamad al-Falimbânî, Siyar as-Salikên ... Juz III, 8-12.
} 
dan zubud, tauhid dan tawakal, cinta dan rindu serta ridha, niat dan ikhlas serta benar, muraqabah dan mubasabah, tafakkur, juga mengingat mati yang pencapaiannya terlihat memperhatikan sistematika pada awalnya, namun pada bagian akhir Shamad terlihat tidak memperhatikan sistematika maqamatnya. ${ }^{64}$

6. Kemunculan Insan Kamil Melalui Tajalli

a. Jumlah Tingkatan Tajalli

Nafis dan Shamad sependapat bahwa kemunculan Insan Kamil melalui tingkatan tajalli. ${ }^{65}$ Konsep tajalli menurut Nafis dan Shamad sama-sama terdiri atas tujuh tingkatan. Konsep tajalli Nafis terdiri atas tujuh tingkatan yakni martabat ahadiyyah, wahdah, wahidiyah, arwah, mitsal, ajsad, dan insan sebagai perwujudan Insan Kamil. ${ }^{66}$ Konsep tajalli Shamad juga terdiri atas tujuh tingkatan, yakni martabat abadiyyah (an la ta'ayun, ithlak, zatul bahtsi), al-wabdah (at-ta'ayun awwal, bakikat Mubammadiyab), alwahidiyyah (hakikat insaniyah), alamul arwah (nur Muhammad), alamul mitsal, alamul ajsam, dan al-jami'ah (martabat insan, at-tajalli akbir). ${ }^{67}$

Nafis tidak mempunyai konsep tajalli dalam tiga tingkatan. Berbeda dengan Shamad yang juga mempunyai konsep tajalli dalam tiga martabat, yakni at-ta'ayyunul awwal, at-ta'ayyunul tsani, dan kharij (terdiri dari alam arwah atau nur Mubammad, alam mitsal, alam ajsam, dan alam insan sebagai perwujudan Insan Kamil. ${ }^{68}$ Berbeda dengan Nafis yang hanya menjelaskan tajalli dalam tujuh tingkatan saja.

b. Nur Mubammad Sebagai Sebab Kesempurnaan Insan Kamil

Nafis dan Shamad mengisyaratkan kesamaan pandangan bahwa nur Muhammad merupakan sebab adanya sesuatu dan sebab kesempurnaan Insan Kamil yang muncul pada martabat terakhir. ${ }^{69}$

c. Kedudukan Nur Muhammad Dalam Tajalli dan Sifat Tiga Martabat Selanjutnya Kesamaan yang penting untuk dilihat antara Nafis dan Shamad adalah kesepakatan meletakkan nur Mubammad pada martabat kedua (martabat wabdab). ${ }^{70}$ Kesamaan lain yang perlu diperhatikan dalam konsep tajalli $\mathrm{Nafis}$ dan Shamad adalah sifat tiga martabat selanjutnya adalah qadim tetapi bukan dalam pengertian waktu melainkan dalam definitif. ${ }^{71}$

Dalam memaknai nur Muhammad. Shamad meletakkan nur Muhammad sebagai asal segala sesuatu pada martabat wahdah. Namun, pada martabat alam arwah dalam tajalli versi Shamad juga ditemukan adanya nur Muhammad. Hal ini sering dikaitkan dengan pendapat bahwa Shamad memandang nur Mubammad tidak bersifat qadim melainkan hadits. Berbeda dengan Nafis yang hanya meletakkan nur Mubammad pada martabat kedua saja. Melihat adanya perbedaan tersebut, penulis berupaya

\footnotetext{
${ }^{64}$ Lihat Shamad al-Falimbânî, Siyar as-Sâlikîn...Juz IV.

${ }^{65}$ Nafis al-Banjari, Ad-Durr an-Nafis..., 21-23. Shamad al-Falimbânî, Siyar as-Sâlikîn ...Juz IV , 103-106.

${ }^{66} \mathrm{Nafis}$ al-Banjari, Ad-Durr an-Nafis..., 21-23.

${ }^{67}$ Shamad al-Falimbânî, Siyar as-Sâlikîn...Juz IV ,103-106.

${ }^{68}$ Shamad al-Falimbânî, Siyar as-Salikîn...Juz IV, 105-106.

${ }^{69}$ Nafis al-Banjari, Ad-Durr an-Nafis..., 21-23. Shamad al-Falimbânî, Siyar as-Sâlikîn ...Juz IV ,103-106.

${ }^{70} \mathrm{Nafis}$ al-Banjari, Ad-Durr an-Nafis..., 21-23. Shamad al-Falimbânî, Siyar as-Sâlikîn ...Juz.IV,103-106.

${ }^{71}$ Nafis al-Banjari, Ad-Durr an-Nafis..., 21-23. Shamad al-Falimbânî, Siyar as-Sâlikîn ...Juz IV, 103-106.
} 
menjembatani kedua pendapat tersebut dengan berpendapat bahwa Shamad memaknai nur Muhammad dalam dua pengertian. Pertama, menunjukkan tajalli'Tuhan yang pertama yang terjadi dalam ilmu Tuhan sehingga bersifat qadim, namun qadimnya berbeda dengan qadim Tuhan. Kedua, menunjukkan tajalli Tuhan dalam arti terbit kepada sesuatu yang mulai berbentuk sehingga bersifat hadits.

Jadi, pandangan Shamad mengenai sifat nur Muhammad berbeda dengan Nafis yang memandang nur Mubammad bersifat qadim sebab berada pada martabat kedua sekaligus asal segala kejadian makhluk, sementara Shamad memandang nur Muhammad dalam dua pengertian yaitu bersifat qadim dalam arti terbit pada martabat kedua dalam ilmu Tuhan sebagai asal kejadian makhluk dan bersifat hadits dalam arti terbit pada martabat alam arwah sebagai asal kenyataan makhluk yang telah berbentuk.

d. Insan Kamil Sebagai Hasil Akhir Tajalli

Konsep tajalli Nafis berakhir pada martabat insan sebagai perwujudan Insan Kamil. ${ }^{72}$ Sedangkan dalam konsep tajalli Shamad diakhiri dengan martabat al-jami'ah (martabat insan, at-tajalli akbir). ${ }^{73}$ Berdasarkan uraian tersebut Nafis dan Shamad terlihat sependapat bahwa Insan Kamil diperoleh setelah mencapai martabat terakhir dalam tajalli.

\section{Interpretasi Terhadap Konsep Insan Kamil Dalam Kitab ad-Durr an-Nafis dan Siyar as-Sâlikîn}

Muhammad Nafis al-Banjari dan Abdush-Shamad al-Falimbânî termasuk ulama utama dalam jaringan ulama Indonesia-Melayu periode abad XVIII M. ${ }^{74}$ Jika melihat waktu kelahiran kedua tokoh ini, Shamad tampak lebih tua sekitar 31 atau 32 tahun dari Nafis. Meskipun demikian, Shamad dan Nafis dapat dikatakan hidup sezaman. Shamad dan Nafis sama-sama banyak menghabiskan waktu untuk menuntut ilmu di Haramayn (Mekkah dan Madinah). Hal tersebut menjadi indikasi bahwa bangunan pemikiran keduanya dipengaruhi oleh situasi dan kondisi yang sama. Tidak ada informasi mengenai kegiatan belajar Nafis bersama Shamad, tetapi kemungkinan masa belajar mereka sama dengan memperhatikan daftar nama-nama guru kedua tokoh tersebut.

Kitab ad-Durr an-Nafis diselesaikan pada tahun $1200 \mathrm{H}$ di Mekkah, ${ }^{75}$ sedangkan kitab Siyar as-Sâlikin diselesaikan pada tahun $1203 \mathrm{H}$ di Thaif Mekkah. ${ }^{76} \mathrm{Hal}$ tersebut mengisyaratkan bahwa kedua kitab diselesaikan pada waktu yang berdekatan dan sama-sama selesai di kota Mekkah. Berdasarkan hal tersebut dapat dikatakan bahwa jika terdapat kesamaan pemikiran dalam kedua kitab tersebut dinilai wajar kedua sebab kedua kitab tersebut muncul dalam setting waktu dan tempat yang sama.

Konsep Insan Kamil Muhammad Nafis dalam kitab ad-Durr an-Nafis dijelaskan melalui formulasi ajaran tauhid dalam bingkai sufisme yang lebih menekankan pandangan mata hati.

\footnotetext{
${ }^{72}$ Nafis al-Banjari, Ad-Durr an-Nafis..., 21-23.

${ }^{73}$ Shamad al-Falimbânî, Siyar as-Sâlikîn...Juz IV, 103-106.

${ }^{74}$ Azra, Jaringan Ulama..., 243.

${ }^{75}$ Tim Sahabat, Syekh Muhammad..., 14. Tim Sahabat, 27 Ulama..., 16-17. Nafis al-Banjari, Ad-Durr an-Nafis..., 2.

${ }^{76}$ Shamad al-Falimbânî, Siyar as-Sâlikîn...Juz IV, 267.
} 
Pembahasan tersebut dianggap sesuai jika melihat kategori kitab yang termasuk ke dalam tingkat muntabi. ${ }^{77}$ Tingkat muntahi diperuntukkan bagi orang yang telah memiliki dasar keilmuan yang mapan.

Konsep Insan Kamil dalam kitab Siyar as-Sâlikîn ditemukan pada beberapa pembahasan terpisah dari berbagai bagian kitab. Kitab Siyar as-Sâlikîn yang lebih banyak memberikan kajian terhadap tasawuf sunni, jika dikaji lebih mendalam akan ditemukan pemikiran yang tidak dapat dikatakan bercorak sunni sepenuhnya, seperti mengenai konsep Insan Kamil. Proporsi kandungan tasawuf sunni yang lebih banyak diungkapkan kitab ini dinilai wajar jika melihat bahwa kategori kitab ini digolongkan ke dalam tingkatan pemula (mubtadi) yang diperuntukan bagi kalangan awam yang baru mempelajari keilmuan agama yang dasar sehingga belum memiliki basis keilmuan yang kuat. ${ }^{78}$ Pembahasan terhadap konsep Insan Kamil dalam kitab Siyar as-Sâlikin yang dinilai sedikit apalagi jika melihat banyaknya pembahasan dan halaman kitab ini secara keseluruhan, dinilai cukup untuk melihat pemikiran pengarangnya terhadap konsep Insan Kamil.

\section{Penutup}

Konsep Insan Kamil yang bersifat elitis tampaknya dapat diterima dengan baik. Hal ini dibuktikan dengan terdapatnya konsep Insan Kamil pada literatur keagamaan yang tidak hanya tergolong muntabi, tetapi juga pada kitab untuk golongan mubtadi. Pembahasan konsep Insan Kamil dalam kitab ad-Durr an-Nafis dan Siyar as-Salikin tidak secara terperinci dijelaskan, melainkan ditelusuri melalui ide-ide tersirat yang diungkapkan pengarang masing-masing kitab yaitu Muhammad Nafis al-Banjari dan Abdus Shamad al-Falimbânî. Dalam mengungkapkan konsep Insan Kamil, kedua tokoh kurang menjelaskan pengertian atau kriteria Insan Kamil tetapi lebih memperhatikan penjelasan terhadap pencapaian atau proses munculnya Insan Kamil.

Konsep Insan Kamil Muhammad Nafis al-Banjari dan Abdus Shamad al-Falimbânî dalam kitab ad-Durr an-Nafis dan Siyar as-Sâlikîn sama-sama merujuk bukan hanya dalam pengertian hasil upaya peningkatan martabat ruhani, melainkan juga sintesis tajalli Tuhan yang sempurna. Hasil upaya peningkatan martabat ruhani yang dimaksud keduanya adalah ma'rifat kepada Allah. Dalam pemikiran Muhammad Nafis, ma'rifat diperoleh setelah berhasil mencapai maqam tauhid af'al. asma, shifat, dan zat secara berurutan. Menurut Abdus Shamad ma'rifat diperoleh setelah berhasil menaklukan tingkatan nafsu ammarah, lawnamah, mulhamah, muthmainnah, radiah, mardhiah, dan kamalah. Pengertian Insan Kamil sebagai sintesis tajalli Tuhan yang sempurna menurut Nafis dan Shamad merupakan martabat terakhir dalam tajalli Tuhan.

Konsep Insan Kamil Muhammad Nafis al-Banjari dan Abdus Shamad al-Falimbânî dalam kitab ad-Durr an-Nafis dan Siyar as-Sâlikîn lebih banyak memiliki persamaan dibandingkan perbedaan. Persamaan yang ditemukan mengenai konsep Insan Kamil dalam kitab ad-Durr anNafis dan Siyar as-Sâlikîn antara lain pengertian Insan Kamil keduanya sama-sama mengarah kepada orang yang telah sampai kepada ma'rifat dan sebagai sintesis tajalli Tuhan, Insan Kamil merupakan pemberian Allah, Insan Kamil harus tetap berpegang pada syariat, derajat tertinggi Insan Kamil adalah Nabi Muhammad SAW, dan puncak akhir maqamat adalah fana dan baqa.

\footnotetext{
${ }^{77}$ Syukur, Filsafat Tasawnf..., 27.

${ }^{78}$ Shamad al-Falimbânî, Siyar as-Sâlikîn...Juz III, 177.
} 
Perbedaan yang tampak dari pemikiran Insan Kamil dalam kitab ad-Durr an-Nafis dan Siyar asSâlikîn adalah mengenai pencapaian atau kemunculan Insan Kamil. Nafis dan Shamad memang sepakat bahwa pencapaian Insan Kamil dilakukan melalui maqamat dan kemunculan Insan Kamil melalui proses tajalli, tetapi menyangkut penjelasan maqamat dan tajalli dalam pemikiran keduanya terdapat sedikit perbedaan. Pencapaian Insan Kamil melalui maqamat versi Nafis dijelaskan melalui pencapaian tauhid secara sistematis yang dimulai dari taubid af'al, dilanjutkan tauhid asma', kemudian tauhid shifat, dan berakhir pada tauhid zat. Dalam konsep Insan Kamil Shamad diungkapkan maqamat melalui metode penyucian hati dengan mendudukkan nafsu. Upaya menundukkan nafsu juga dilakukan secara sistematis yang dimulai dari ammarah, lalu lawwamah, kemudian mulhamah, dilanjutkan muthmainnah, seterusnya radiah, lalu mardhiah, dan berakhir kamalah.

Konsep Insan Kamil yang diungkapkan dalam kitab ad-Durr al-Nafis dan Siyar as-Sâlikîn berorientasi pada pemikiran telogis-filosofis. Konsep Insan Kamil yang ditawarkan berorientasi demikian, sebab pembahasan konsep Insan Kamil berangkat dari pemahaman tauhid yang bertingkat hingga mencapai tingkat tinggi, selain itu konsep Insan Kamil dalam kedua kitab juga dijelaskan melalui konteks pemikiran filsafat yang dipadukan dengan tasawuf terutama dalam menjelaskan tajalli.

\section{DAFTAR PUSTAKA}

Abdullah, Mal An. Abdus Samad al-Palimbani Data Baru Tentang Hayat dan Karyanya. t.t. (22 Desember 2014).

Akbarizan. Tasawuf Integratif Pemikiran dan Ajaran Tasawuf di Indonesia. Pekanbaru: Suska Press, 2008.

Ali, Yunasril. Manusia Citra Ilahi Pengembangan Konsep Insan Kamil Ibn 'Arabi oleh al-jili. Jakarta: Paramadina, 1997.

Armstrong, Amatullah. Kunci Memasuki Dunia Sufi, terj. M. S. Nashrullah dan Abmad Baiquni. Bandung: Mizan, 2001.

As, Asmaran. Pengantar Studi Tasawuf. Jakarta: Raja Grafindo Persada, 1994.

Azra, Azyumardi. Jaringan Ulama Timur Tengah dan Kepulauan Nusantara Abad XVII dan XVII Melacak Akar-Akar Pembaruan Islam di Indonesia. Bandung: Mizan, 1998.

Al-Banjari, Muhammad Nafis ibn Idris. Ad-Durr an-Nafis fi Bayan Wabdat al-Af'al wa al-Asma' wa ash-Shifat Zat at-Taqdis. Singapura, Jedah, Indonesia: Haramayn, t.th.

Ad-durrunnafis, alih bahasa Haderanie HN dengan judul Ilmu Ketuhanan Permata yang Indah Ad-durrunnafis. Surabaya: Nur Ilmu, t.th.

Al-Banjari, Waini Hambali. Manakib Syekh Abdush Shamad al-Falimbani. Kandangan: Sahabat, 2012.

Bruinessen, Martin Van. Kitab Kuning Pesantren dan Tarekat Tradisi-Tradisi Islam di Indonesia. Bandung: Mizan, 1999.

Chittick, William C. Kosmologi Islam dan Dunia Modern, terj. Arif Mulyadi. Jakarta: Mizan Publika, 2010.

Dahlan, Bayani, ed., Ulama Banjar dan Karya-karyanya. Banjarmasin: Antasari Press, 2009.

Dewan Redaksi Ensiklopedi Islam. Ensiklopedi Islam. Jakarta: Ichtiar Baru van Hoeve, 2001. 
Al-Fahamah, Mawlana al-'Allamah. Hakikat Jalan Sufi Keesaan Af'al Asma' Shifat dan Drat yang Suci, terj. Agus Wahyudi (Yogyakarta: Qalam, 2003).

Al-Falimbani, Abdus Shamad. Hidayatus Salikin fi Suluki Maslakil Muttaqin Petunjuk Jalan Bagi Orang yang Takut Kepada Allah Taala, pentahqiq Ahmad Fabmi bin Zamzam, Banjarbaru: Darussalam Yasin, 2008.

. Sairus Salikin (Perjalanan Orang yang Salik Kepada Allah) Juz Pertama, pentahqiq Ahmad Fahmi bin Zamzam. Banjarbaru: Darussalam Yasin, 2010.

. Sairus Salikin (Perjalanan Orang yang Salik Kepada Allah) Juz Kedua, pentahqiq Ahmad Fahmi bin Zamzam. Banjarbaru: Darussalam Yasin, 2010.

. Sairus Salikin (Perjalanan Orang yang Salik Kepada Allah) Juz Ketiga, pentahqiq Ahmad Fahmi bin Zamzam. Banjarbaru: Darussalam Yasin, 2010.

. Sairus Salikin (Perjalanan Orang yang Salik Kepada Allah) Keempat, pentahqiq Ahmad Fahmi bin Zamzam. Banjarbaru: Darussalam Yasin, 2010.

. Siyar as-Sâlikîn fi Thariqah as-Sâdât ash-Shûfîyah Juz I. Singapura, Jedah, Indonesia: Haramayn, t.th.

. Siyar as-Sâlikîn fi Thariqah as-Sâdât ash-Shûfîyah Juz II. Singapura, Jedah, Indonesia: Haramayn, t.th.

. Siyar as-Sâlikîn fi Thariqah as-Sâdât ash-Shûfiyah Juz III. Singapura, Jedah, Indonesia: Haramayn, t.th.

. Siyar as-Sâlikîn fi Thariqah as-Sâdât ash-Shûfiyah Juz IV. Singapura, Jedah, Indonesia: Haramayn, t.th.

Faridy, Heri, Rahmat Hidayat, dan Ika Prasasti Wijayanti, ed., Ensiklopedi Tasawuf Jilid II. Bandung: Angkasa, 2008.

Fathurahman, Oman. Ithaf al-Dhaki Tafsir Wahdatul Wujud Bagi Muslim Nusantara. Bandung: Mizan, 2012.

Glasse, Cyril. Ensiklopedi Islam (Ringkas), terj, Ghufron A. Mas'adi. Jakarta: Raja Grafindo Persada, 2002.

Huda, Nor. Islam Nusantara Sejarah Sosial Intelektual Islam di Indonesia. Yogyakarta: Ar-Ruzz Media, 2007.

Isa, Ahmadi. Ajaran Tasawuf Muhammad Nafis Dalam Perbandingan. Jakarta: Raja Grafindo Persada, 2001.

Ismail, Asep Usman. Apakah Wali Itu Ada? Menguak Makna Kewalian Dalam Tasawuf Pandangan al-hakim al-Tirmidji dan Ibn Taymiyyah. Jakarta: Raja Grafindo Persada, 2005.

Jumantoro, Totok, dan Samsul Munir Amin. Kamus Imu Tasawnf. T.t: Amzah, 2005.

Labib, Muhsin. Mengurai Tasawuf Irfan \& Kebatinan. Jakarta: Lentera, 2004.

Miri, Seyyed Mohsen. Sang Manusia Sempurna Antara Filsafat Islam dan Hindu, terj. Zubair. Jakarta: Teraju, 2004.

Mulyati, Sri. Tasawnf Nusantara Rangkaian Mutiara Sufi Terkemuka. Jakarta: Kencana, 2006.

Muthahhari, Murtadha. Manusia Sempurna, terj. Helmi Mustofa. Yogyakarta: Al-Ghiyatd Prisma Media, 2004.

Nasr, Seyyed Hossein. The Garden of Truth Mereguk Sari Tasawnf, terj. Yuliani Liputo. Bandung: Mizan, 2010. 
Nasution, Harun, dke, ed. Ensiklopedi Islam I. Jakarta: Anda Utama, 1993.

Nata, Abuddin. Akblak Tasawnf. Jakarta: Raja Grafindo Persada, 2009.

Shihab, Alwi. Islam Sufistik Islam Pertama dan Pengarubnya Hingga Kini di Indonesia. Bandung: Mizan, 2001.

Solihin, M. Sejarah dan Pemikiran Tasawuf di Indonesia. Bandung: Pustaka Setia, 2001.

Suryadilaga, Fatih. Miftahus Sufi. Yogyakarta: Teras, 2008.

Syukur, M. Asywadie. Filsafat Tasawnf dan Aliran-alirannya. Banjarmasin: Antasari Press, 2009.

Tim Penulis, LAIN Syarif Hidayatullah. Ensiklopedi Islam. Jakarta: Djambatan, 1992.

Tim Sahabat. 27 Ulama Berpengarub Kalimantan Selatan. Kandangan: Sababat, 2010.

Nafis, Syekh Muhammad al-Banjari dan Ajarannya. Kandangan: Sahabat, 2010.

Yunus, Mahmud. Kamus Arab Indonesia. Jakarta: Hidakarya Agung, 1990. 